\title{
Resenha
}

\section{Benedito Calixto: um pintor caiçara}

Arte acadêmica, pré-moderna, just milieu, naturalista, realista e impressionista. Todas estas classificações foram feitas por críticos e estudiosos da arte para a obra artística produzida por Benedito Calixto de Jesus (Itanhaém, 1853 - São Paulo, 1927).

O Professor Caleb Faria Alves perscrutou com acuidade a trajetória de vida e o fazer artístico desse pintor paulista e conseguiu mostrar a complexidade do campo cultural brasileiro, especialmente o paulista. Evidentemente, que sua análise teve como norte a teoria dos campos do sociólogo francês Pierre Bourdieu, mas seus argumentos ultrapassaram as balizas teóricas da obra bourdiana.

O autor mostrou um pintor que transcendia as simples classificações, porque Benedito Calixto teve uma "trajetória híbrida": adveio de uma origem artesã; não freqüentou a tradicional Academia Imperial de Belas Artes no Rio de Janeiro; sua viagem à Paris deveu-se ao mecenato de Nicolau de Campos Vergueiro (Visconde de Vergueiro), na época presidente da Associação Comercial de Santos; sua estada em Paris mostra que freqüentou o ateliê de Jean François Rafaëlli e, depois que travou contato com Victor Meirelles mudou-se para a Académie Julian onde passou pelos ateliês de Tony Robert-Fleury, Gustave Boulanger, Jules Lefebvre e William Bouguereau; suas influências artísticas são difíceis de detectar porque em termos de formação parece não ter havido grandes variações entre os professores da Académie Julian e da École des Beaux-Arts, entretanto, teve conhecimento com a arte acadêmica, com o impressionismo e com o naturalismo português do "Grupo do Leão", além de vivenciar as "fissuras da Academia" como a querela travada na imprensa pelo crítico de arte Luiz Gonzaga Duque Estrada sobre os quadros das Batalhas do Avahy e dos Guararapes de Pedro Américo e Victor Meirelles

1 ALVES, Caleb Faria. Benedito Calixto e a construção do imaginário republicano. Bauru: EDUSC, 2003. 344 p. il. (Coleção Ciências Sociais).

Estudos Ibero-Americanos. PUCRS, v. XXX, n. 2, p. 131-133, dezembro 2004 
exibidos na Exposição Geral de Belas Artes de 1879, na qual o crítico vislumbrou que "se a pintura moderna é a pintura de multidão, isto é, a pintura para o povo; se ela é feita para impressionar, para fazer sentir a realidade; como exigir do artista a calculada composição de linhas acadêmicas?".

O Professor Caleb Faria Alves conseguiu mostrar que: "A construção da identidade do pintor, as características de sua pintura e a história do Estado [São Paulo] se confundem, se mesclam numa única matriz imaginária. Foi esse processo que permitiu a Calixto alçar-se à posição de pintor. A limitação dessa posição revelou-se, entretanto, na intensidade com que o hábito visual engendrado dependia dos agentes do campo político".

Reside aqui, o papel de Benedito Calixto na construção do imaginário republicano, ou seja, na "invenção da tradição" [aqui, utilizada na acepção de Eric Hobsbawn e Terence Ranger] do Estado de São Paulo. Entre as questões discutidas, o autor mostrou que na busca incessante por uma arte genuinamente nacional, Calixto teve sua carreira profundamente identificada com a elaboração de uma iconografia paulista associada ao acervo do Museu Paulista sob a direção de Afonso d'Escragnolle-Taunay e com a colaboração do Instituto Histórico e Geográfico de São Paulo.

No afã da construção da imagem do 'paulista', o sociólogo construiu uma genealogia de autores e artistas que ajudaram a forjar uma visualidade que fosse identificável com a terra e o homem de São Paulo, desde os relatos e imagens dos viajantes estrangeiros até o quadro de Pedro Américo "Independência ou Morte" (1888), não olvidando a construção do 'caipira' por Almeida Júnior em "O derrubador" (1879).

Pela análise do autor, o que se implanta em São Paulo é "um sistema híbrido": "Não está centrado na "pintura", como o sistema acadêmico, com seus prêmios e concursos, mas também não está centrado no artista, como o sistema moderno, com toda uma gama de especialistas na promoção da pessoa do pintor. São Paulo tem características de ambos os sistemas. Por um lado, o artista está muito mais preocupado em construir sua imagem de identidade com o solo, com as tradições e a natureza local: ele é caipira, como Almeida Júnior, ou caiçara, como Benedito Calixto. Por outro lado, a sua consagração depende grandemente de sua presença no $\mathrm{Mu}$ seu Paulista, ou seja, da promoção do Estado; e isso sem concursos, mas em conseqüência da afinidade com o projeto simbólico republicano e por intermédio das relações com os dirigentes". 
O livro de Caleb Faria Alves se inscreve entre os inovadores trabalhos acadêmicos de Sociologia da Cultura no Brasil, que tem como núcleo a Universidade de São Paulo (USP), com os estudos de Sérgio Miceli e Maria Arminda do Nascimento Arruda. Este livro foi originalmente tese de doutorado, defendida em 2001, junto ao Programa de Pós-Graduação em Sociologia da USP, sob a orientação da Professora Doutora Maria Arminda do Nascimento Arruda, que prefaciou a obra.

Ao longo dos quatro capítulos que compõem o livro: Ingressando na carreira artística, Um caiçara em Paris, As fissuras da Academia e Imagens da transformação; o autor conseguiu demonstrar com argúcia o quão complexa é a discussão sobre a configuração do campo artístico brasileiro, especialmente o de São Paulo que se imbricava com a trajetória artística de Benedito Calixto. O que o levou a seguinte conclusão, que Calixto, Pedro Américo, Taunay, entre outros, elaboraram uma "estética própria" e, mais ainda, um hábito visual, que pode ser expresso no dito popular: "O Rio de Janeiro é um presente de Deus aos olhos dos homens, São Paulo é um presente do homem aos olhos de Deus".

E, sobre a trajetória artística de Benedito Calixto, "nunca foi uma unanimidade, não foi "mestre", como os acadêmicos, não foi dândi, boêmio ou moderno. Eternamente, um artista que construiu sua imagem como pintor caiçara".

Maria de Fátima Fontes Piazza*

* Doutora em História e Professora do Departamento de História da Universidade Federal de Santa Catarina 